\title{
Forest Biomass Availability and Utilization Potential in Sweden: A Review
}

\author{
Anuj Kumar ${ }^{1} \cdot$ Stergios Adamopoulos $^{2}$ (1) $\cdot$ Dennis Jones ${ }^{3} \cdot$ Stephen O. Amiandamhen ${ }^{2}$
}

Received: 17 October 2019 / Accepted: 25 January 2020 / Published online: 31 January 2020

(C) The Author(s) 2020

\begin{abstract}
In recent years, there has been a growing interest in many parts of the world for more effective biomass utilization due to legislative and public interest in sustainable development. Whilst much of the effort has been on energy generation from biomass, there is considerable interest on biomass availability and utilization for other end uses. With about $1 \%$ of the world's commercial forest areas, Sweden provides about $10 \%$ of the sawnwood, and pulp and paper that is traded on the global market. The Swedish agricultural sector also contributes to biomass availability, not only by production of sustainable food crops, but also by utilizing side streams and underutilized land for biomaterial purposes. To meet the challenges that climate change presents, there has to be a shift to sustainable biomass production and increased interest in promoting a circular bioeconomy. This review presents a systematic assessment on the availability of biomass and its utilization potential in Sweden. The review also focuses on biomass production and trade in the Swedish forest industry. In addition, the environmental impact of biomass utilization is discussed.
\end{abstract}

\section{Graphic Abstract}

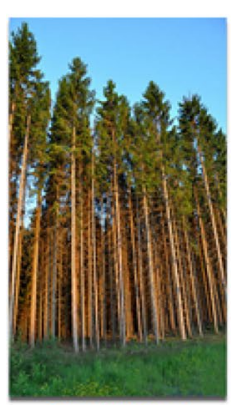

Swedish forest

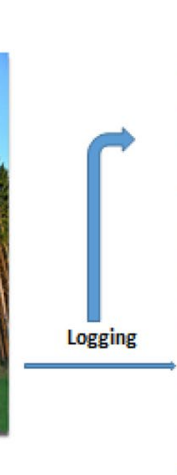

.

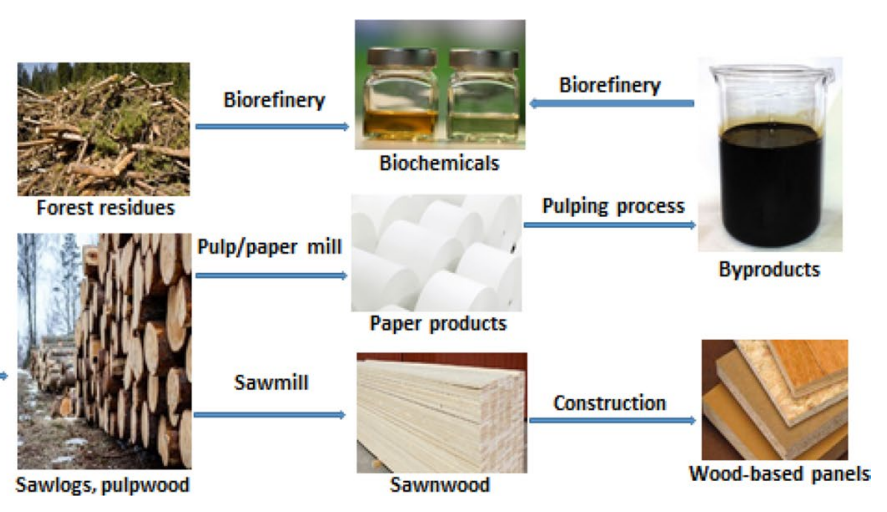

Keywords Biomass $\cdot$ Environmental impact $\cdot$ Pulp and paper $\cdot$ Sawnwood $\cdot$ Sweden

Stergios Adamopoulos

stergios.adamopoulos@lnu.se

1 Natural Resources Institute Finland (Luke), Maarintie 6, 02150 Espoo, Finland

2 Department of Forestry and Wood Technology, Faculty of Technology, Linnaeus University, Lückligs Plats 1, 35195 Växjö, Sweden

3 Department of Engineering Sciences and Mathematics, Wood Science and Engineering, Luleå University of Technology, 93187 Skellefteå, Sweden

\section{Statement of Novelty}

There has been a number of literature studies on biomass availability with regard to bioenergy potential. This work comes in a series of studies conducted to explore the potentials of Swedish forest biomass in prosmoting a sustainable bioeconomy. However, the authors are not aware of any paper that specifically addresses forest biomass for nonenergy utilization in Sweden. The novelty of this paper is that it presents an assessment on biomass availability and 
utilization by the Swedish forest products industries, including biorefineries within the Swedish context.

\section{Introduction}

Biomass utilization has increased significantly in Sweden over the last few decades. Although forest resources and agricultural crops are the main biomass categories available in Sweden, a small percentage including logging residues and energy crops are directed towards energy generation. More than half the land area of Sweden, about 57\% or 23 million hectares is covered by forests, making forest biomass the likely source for any substantial increase in renewable energy use and sustainable production. Whilst Sweden only has $1 \%$ of the total global forest cover, it accounts for more than $10 \%$ of the global forest industry business, which includes sawn timber, and pulp and paper products. It is estimated that available wood will drop from 2020 to 2030 in Sweden, but a major swing in markets supplied would occur with high mobilization, with more felled timber going to energy [1]. Sawn products would then drop from around $75 \%$ under business as usual conditions to around $60 \%$ for high mobilization scenarios.

The European forest industries recognized the importance of developing innovative forest-based products with higher added value to meet societal demands for materials, energy, employment, and environmental protection [2]. According to the National Research Agenda for the Swedish forest-based sector, developing and producing forest products with higher added value is an important strategic goal [3]. It is generally understood that shifting from high volume production of low-value goods to selective production of higher-value goods will increase the contribution to local and national economies from both limited resources of forest land and sustainably harvested forest biomass. However, the knowledge on specific ways to achieve this goal is incomplete. Whilst the production and export of sawnwood and paper products has increased steadily over the last few years, the future market of paper and wood products is uncertain, since it may be affected by biomass availability factors. The availability and utilization potential of forest biomass depends on the annual increment in forest volume and the annual demand of stem wood for building and other applied industrial purposes. Using a 20-year forecast, Börjesson et al. [4], predicted a balance between the demand for round wood for pulp and saw $\operatorname{logs}$ and the annual increment in Swedish forests around 2020. It was estimated that the increment in European forests would exceed the demand for stem wood for industrial purposes in Europe.

An assessment of biomass availability and quality is an important approach towards understanding its utilization potential in various sectors. There are already several publications and a number of scenarios that predict biomass potential with regard to bioenergy [5-7]. This review specifically presents a detailed assessment of Swedish forest biomass by evaluating its gross availability, quantity and conversion and utilization. The paper also highlights some aspects of biomass production and utilization in the Swedish agricultural sector. An overview of the Swedish forestry sector is also presented as the main contributor of biomass. The environmental considerations in biomass utilization and the future prospects for a sustainable biobased economy are discussed herein. The overall aim is to share the Swedish experience in forest biomass production and utilization with an international audience since this development is fairly well-known in Sweden.

\section{Overview of Swedish Forest Sector}

The first modern Forestry Act in Sweden was passed in 1903. At that time, the country's forests had substantially decreased. An important objective of the Forestry Act was to secure the supply of wood for the future. A measure of how forestry has succeeded is that between 1950 and today, the standing volume has increased by $200 \%$, from 1 to 3 billion cubic meters. The forest standing stock in Sweden has nearly doubled over the last century. Currently, the average growth rate of Swedish forests is 5.1 cubic meters $\mathrm{ha}^{-1}$ year $^{-1}$ [8]. A number of studies have suggested that changes in management practices can lead to substantial $(>50 \%)$ increases in forest growth, which would increase the long-term future potential of biomass harvest $[9,10]$. Forestry and forest products have long been a key resource for the Swedish economy [11], supported by regular updates of national forest inventories since the original publication in 1923 [12]. As a result, Sweden has a unique set of longterm data describing the forest resource on regional as well as national bases. This is further enhanced with a long tradition of analyzing the consequences of different management practices [13] and well developed tools for modeling forest growth [14]. In addition, Sweden is well suited for analyzing the climate mitigation effects of active forest management in the boreal region.

In Sweden alone, forests cover $70 \%$ of the country's area, with around 87 billion trees. There is now twice as much timber in Sweden as there was 90 years ago. About $1 \%$ of Sweden's forest is felled annually [13], and for every tree harvested, at least two new trees are planted. The substitution effect of Swedish forest industry products is equivalent to Sweden's annual carbon dioxide emissions. Since the Swedish Forestry Act was updated in 1993, environmental and production targets in forestry have been brought in line with each other. Sweden's forest industry has reduced its 
emissions by over $60 \%$ since 2005 and uses almost no fossil fuels in its processes, as $96 \%$ of the heating energy used by the forest industry is bioenergy. Of the country's total greenhouse gas (GHG) emissions, the forest industry accounts for around $1 \%$. Electricity consumption in the forest industry is around 20 TWh per year, which is just over 15\% of Sweden's total electricity consumption [13].

The forest sector (including wood industry and pulp and paper industry) contributes about 5\% to Swedish GDP [15]. As the world's third largest exporter of forest products, Sweden exports $90 \%$ of pulp and paper products and about $70 \%$ of sawn timber products. The export value in 2018 was SEK 145 billion with SEK 15.4 billion of total investment, and almost $80 \%$ of the products were exported [16]. Every year, Sweden invests SEK 2 billion in forest research at universities, colleges and institutes. Forest industry companies also invest annually SEK 2.3 billion in their own research. According to the Swedish Forest Industries Federation [16], its members constitute 50 pulp and paper mills, 120 sawmills and 40 companies closely connected to the production of pulp, paper or timber goods. In terms of volumes, Swedish forest industries produced about 12 million tons of pulp (of which 4.3 million tons are market pulp), 11.3 million tons of paper and 18.3 million cubic meters of sawn timber in 2018 [16].

The Swedish forest ownership is distributed into six classes. Almost half of forest is owned by individual farmers, another $25 \%$ is privately owned limited companies, and the rest $25 \%$ forest is distributed between state-owned limited companies (14\%), other private owners (6\%), the state (3\%) and other public owners (2\%). Scots pine and Norway spruce are the two dominant tree species growing in Sweden, comprising 39\% and $42 \%$ respectively of the total forest volume, with the remaining $19 \%$ comprising broad-leaved species. In terms of annual production, approximately $45 \%$ (around 40 million cubic meters) becomes timber. This in turn becomes furniture, construction timber, boards and planks, and other wood products. About 40-45\% (i.e. 35 million cubic meters) becomes pulpwood from which newspapers, packaging and other paper products are made, whilst just under 10\% (i.e. 8-9 million cubic meters) becomes biofuel, which is then used for electricity and heating.

The Swedish forest sector continues to pursue growth in the world's bioeconomy sector by research and development. Based on the Swedish forest research agenda [17], the priorities of the forest sector include:

- Maintaining the competitiveness of existing production facilities in order to maintain profitability, but also to finance the development of new bio-based products and processes;

- Increasing the availability of forest raw materials whilst maintaining sustainable forestry;

- Developing new bio-based products to replace today's fossil-based materials and products;

- Stimulating an increase in industrial timber constructions to achieve more sustainable buildings;

- Increasing international research cooperation, since the market is international.

\section{Biomass in Sweden}

The classification of biomass is essential in understanding different biomass types and situations. In general, biomass can be classified based on its origin, characteristics, composition and disposal methods [18]. Roberts et al. [7] classified biomass into different categories as shown in Fig. 1. Based on the origin, biomass can be classified into vegetable and animal derived biomass. Vegetable biomass can be sub-classified into natural, residual and energy biomass. Natural and energy biomass are virgin crops while residual biomass are further classified into forest, agricultural, industrial and municipal solid wastes. Increasing urban population and activities are responsible for the generation of industrial processing residues, municipal solid waste, and other urban discards. This section discusses the
Fig. 1 Biomass classification based on the origin [7]

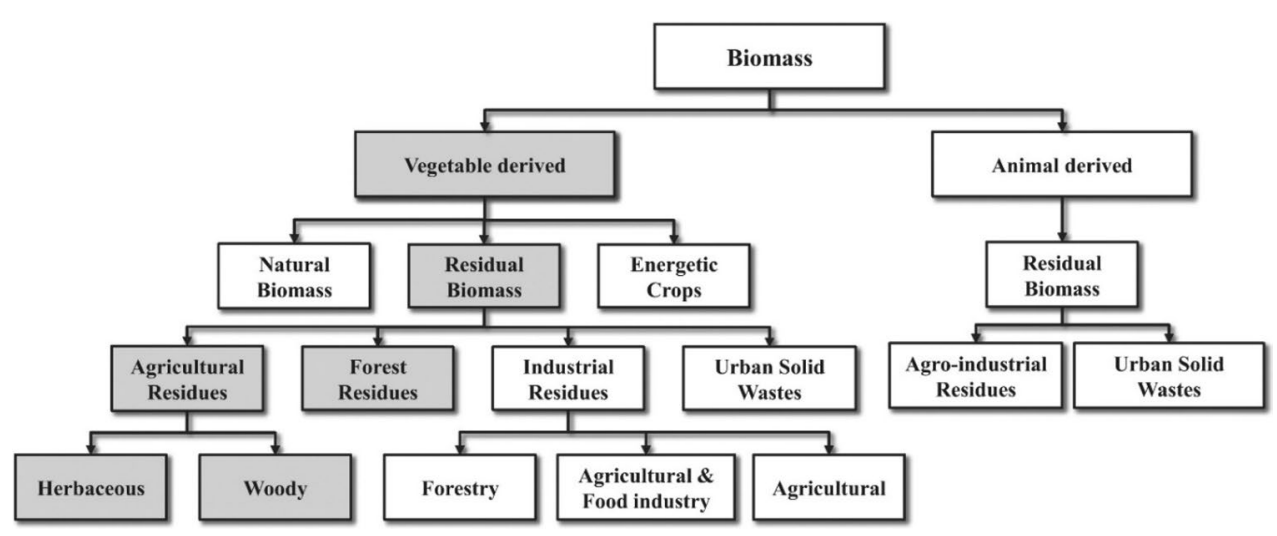


natural forest biomass available in Sweden. The potential of Swedish agricultural sector is also briefly discussed.

\section{Forest Biomass Availability}

Forest biomass availability depends on adequate economic and environmental conditions. Depending on the climate and crop-harvesting schedule, there can be seasonal constraints on biomass availability and significant annual variability in resource yields at a local level [19]. Adverse environmental conditions can have significant negative or positive impacts on annual resource availability. The total forest biomass in Sweden is increasing and is currently about 1750 million tons dry weight [20]. This represents the theoretical potential which may be different from realizable biomass potential. Given the steady growth in the demand for bio-based products, Sweden has invested significantly in biomass availability and supply security. Different processes are used to assess forest biomass availability. Some assessments ascertain biomass potential for a sustainable utilization, as well as the social, environmental, and economic impacts associated with resources production and use [19]. Other assessments analyze biomass potential using detailed forest inventory database while considering the constraints that reduce biomass availability for different mobilization scenarios [21]. Biomass resource assessments guide industry development strategies and support decision-making processes. Generally, attempts are made for developing biomass functions from stem diameter and height, which give better coefficient of determination for stem biomass prediction [5]. Statistical analysis revealed that diameter at breast height was the best predictor for the aboveground biomass.

The Swedish forest sector is defined to include wood resources as well as the use of these resources, i.e., forest products and energy uses of wood. According to Sandberg et al. [22], forest products include all the primary wood products manufactured in the forest processing sectors (sawnwood, wood-based panels, paper and paperboard) and the main inputs or partly processed products used in other sectors (round wood, pulpwood, wood residues, recovered paper). Secondary or value added forest products (such as wooden doors, window frames and furniture) are not covered, although trends in these markets have been taken into consideration. Traditionally, forest supplies the sawn timber and pulpwood used by the forest industries. In the Swedish forest sector, raw material imports are fed into the primary processing level. The total biomass comprising sawn timber and pulpwood is then used by sawmill and the wood fiber industries to manufacture products for both national and international markets as presented in Fig. 2.

The forest not only supplies the sawnwood and pulpwood, it also provides forest thinning, logging residues and forest undergrowth used in the bioenergy sector. These resources may have some seasonal variability, but typically remain at consistent levels in most areas. They also tend to be more spatially concentrated [19]. The bioenergy sector also utilizes all sorts of wastes and side streams from saw logs and pulpwood. These residues are used in producing biofuel for heat and electricity generation, as well as producing pellets for heating and liquid biofuels for transport. Besides fuel production, there has been a growing interest in the development of other biorefineries to develop economically viable products and chemicals as substitutes to those produced in traditional oil refineries [23]. The side streams of pulp and paper products are utilized in these biorefineries in producing value-added chemicals and consumer products. Figure 3 shows the conversion pathway for the Swedish forest biomass. Apart from forest biomass, agricultural and energy crops represent alternative primary renewable biomass sources in Sweden. Energy crops are important biomass
Fig. 2 Wood flow for the forest industries 2017 [16]

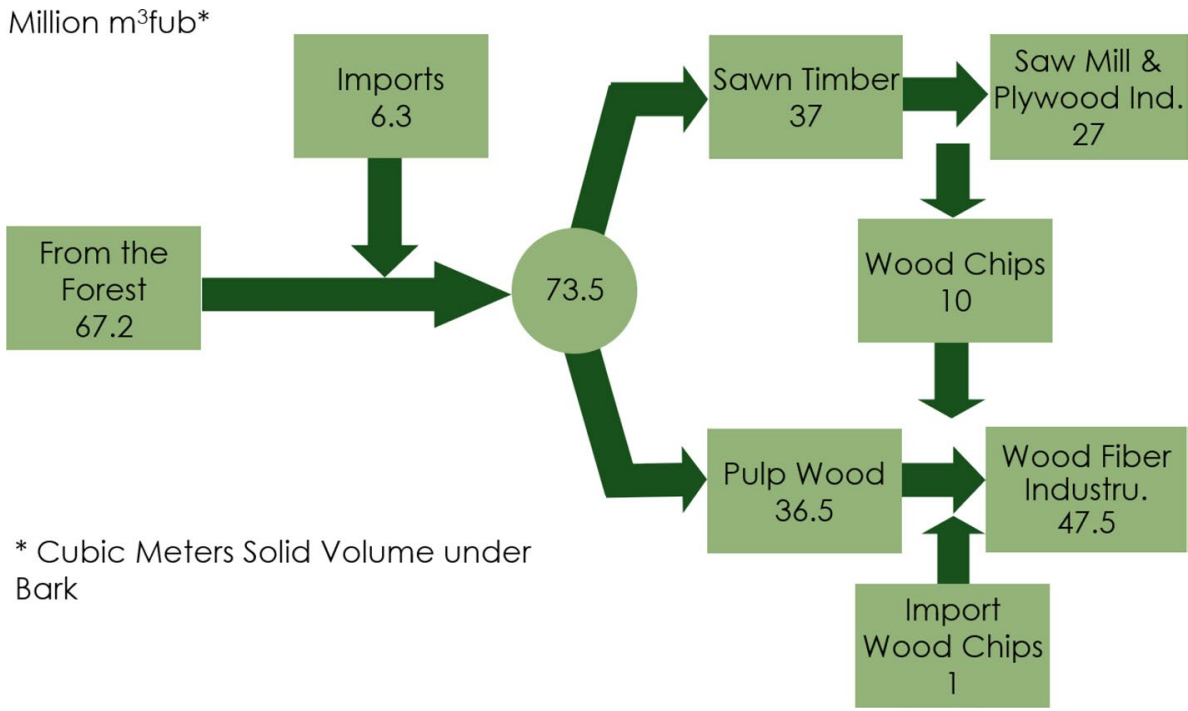




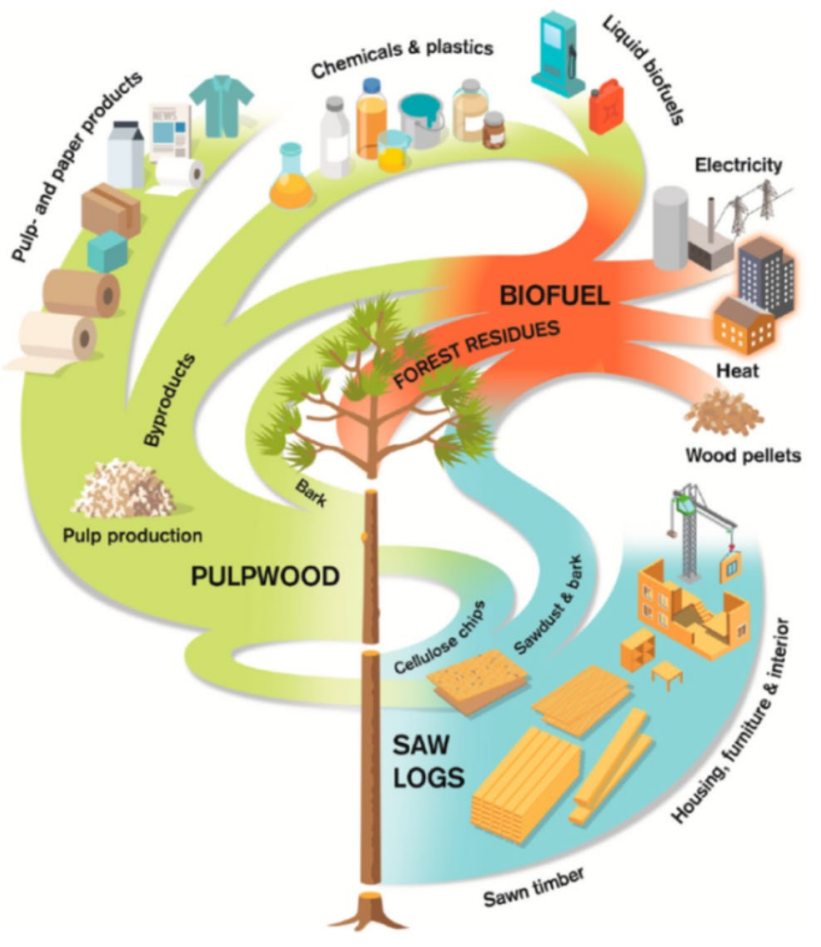

Fig. 3 Forest biomass conversion [24]

specifically grown for bioenergy, and they are mostly cultivated in transitioned grasslands. Energy crops mostly include fast growing tree species such as Salix and Populus with rotation periods of 5-10 years. After cultivation, the entire biomass is used for energy generation. It should be noted that the bioenergy sector is not part of this review and will not be analyzed further in the following sections.

\section{Agricultural Sector}

The Swedish agricultural sector has the potential to contribute more to the development of a sustainable economy. This is achieved not only by the production of sustainable food crops but also utilizing side streams of agri-industries and underutilized land for biomaterial sourcing. In the last 20 years, the agricultural area has decreased its contribution to the gross domestic product (GDP) from approximately $1 \%$ to less than $0.3 \%$ such that the national contribution to GDP was SEK 4.4 million in 2016. The total arable land used in Sweden today is about 2.5 million acres, whilst a further 450,000 acres are used as pastureland [25]. Other than food crops, there are small areas for farming energy crops, however not to a great extent. Profitability might be one reason for the small volumes, since there are vast volumes of forest biomass byproducts, organic waste and also cereals that are used for conversion to energy streams. The future prospects of using materials from the agricultural sector highly depend on the available land for non-food crops.
The available material streams are dependent on the overall profitability and today, most of the materials are used in energy related streams.

\section{Biomass Utilization in Sweden}

As already discussed, Swedish forest biomass has a wide variety of uses, including traditional industrial uses for sawnwood products and pulp and paper production, as well as in the energy sector for combined heat and electricity generation. In addition, it is of considerable interest for the development of continuous largescale production of advanced liquid and gaseous biofuels [26]. Thus, Swedish forest biomass represents an important component within the available local, national and regional supply of renewable raw materials. The following sections discuss the Swedish forest industries, their products and market potentials.

\section{Sawmills}

Swedish sawmills have a long history and have played a significant role in the economic development of the country. The history of Swedish sawmills can be divided in two phases. The first phase was from 1850 to 1900 , which began with the establishment of sawmills, and then it became a leading export sector by the end of the nineteenth century. The second phase was from 1900 to 1990, comprising constant developments and overcoming several crises including the World Wars, the oil crisis of the 1970s, and competition from pulp and paper industrial developments [27]. The future of sawmilling in Sweden depends on some important factors necessary to meet the global demands and business opportunities. Some of these include: increasing the size of the firm, skill and knowledge transfer, encouraging the use of wood in 'green building', product diversification or value added strategy, improved technology and mechanization [28-30].

Currently, Sweden is the largest softwood exporter in Europe with 12.4 million $\mathrm{m}^{3}$ exports out of 18.2 million $\mathrm{m}^{3}$ production in 2018. Table 1 shows the national production, import and export data of sawnwood in Sweden compared with Europe from 2014 to 2018. In Sweden, the production of sawn softwood has been fairly stable during this period, showing a slight improvement from 17.4 million $\mathrm{m}^{3}$ (2014) to 18.2 million $\mathrm{m}^{3}$ (2018). The exports of sawn softwood also increased from 12.1 million $^{3}$ to 12.4 million $\mathrm{m}^{3}$ within the same period. In the European market, the export of sawnwood increased steadily from $71.1 \mathrm{mil}-$ lion $\mathrm{m}^{3}$ in 2014 to 88.1 million $\mathrm{m}^{3}$ in 2018 [26]. In Sweden, the domestic consumption of sawn softwood showed 
Table 1 Production, import and export of sawnwood in Sweden compared with Europe [32]

\begin{tabular}{llllllll}
\hline Sawnwood & Value $\left(\mathrm{m}^{3}\right)$ & Region & 2014 & 2015 & 2016 & 2017 \\
\hline Sawnwood, coniferous & \multirow{2}{*}{ Production } & Sweden & $17,400,000$ & $18,074,000$ & $18,260,000$ & $18,309,000$ & $18,273,000$ \\
& & Europe & $133,452,732$ & $136,331,722$ & $141,906,718$ & $149,109,630$ & $153,871,383$ \\
& \multirow{2}{*}{ Import } & Sweden & 408,980 & 409,648 & 429,257 & 485,766 \\
& & Europe & $32,906,321$ & $33,310,193$ & $34,698,263$ & $37,436,315$ & $38,464,805$ \\
& \multirow{2}{*}{ Export } & Sweden & $12,131,470$ & $12,827,600$ & $12,996,000$ & $13,110,654$ & $12,437,000$ \\
& & Europe & $71,170,766$ & $73,845,714$ & $78,953,745$ & $84,782,337$ & $88,181,215$ \\
Sawnwood, non-coniferous all & \multirow{2}{*}{ Production } & Sweden & 100,000 & 100,000 & 97,000 & 97,000 & 100,000 \\
& & Europe & $13,913,555$ & $13,972,830$ & $14,527,078$ & $15,917,149$ & $16,263,426$ \\
& \multirow{2}{*}{ Import } & Sweden & 27,720 & 28,436 & 42,709 & 45,983 \\
& & Europe & $4,518,772$ & $4,592,643$ & $4,787,586$ & $4,886,176$ & $4,915,750$ \\
& \multirow{2}{*}{ Export } & Sweden & 9270 & 4732 & 19,301 & 42,715 \\
& & Europe & $6,911,202$ & $7,787,892$ & $7,951,709$ & $8,685,840$ \\
\hline
\end{tabular}

very significant improvement due to rapid development of engineered wood products and increased demands of such products, especially cross-laminated timber (CLT) in the building sector [31]. On the other hand, sawn hardwood had steady or slightly decreased production, while import and export figures during the period have been markedly variable (Table 1). Sweden is the single largest market for the Swedish sawmills, with usage in 2017 rising to 5.5 million $\mathrm{m}^{3}$ [31]. This demand has been driven by a strong housing activity, which climbed to its highest level since the early 1990 s and was estimated to increase by $10 \%$ to 70,000 units in 2017. Also, the demands in retrofitting and maintenance activity has remained at a healthy level [16].

Statistics from sawmill database [33] showed that the production of sawn timber in Sweden was undertaken by 265 active sawmills, generating SEK 26.7 billion in revenue.
Fig. 4 Different side streams in sawmill operations

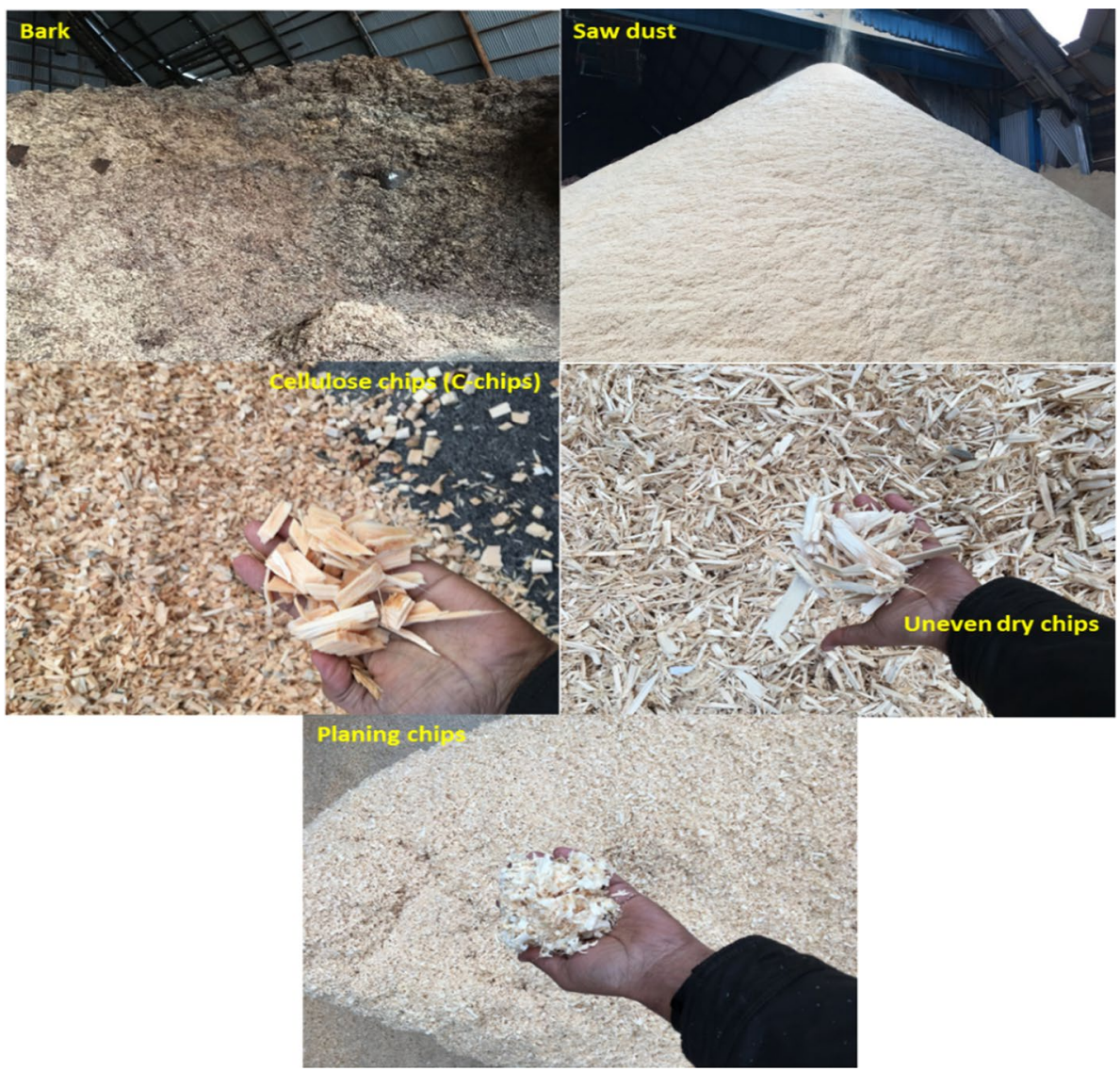


Sawmilling operations also generate various side streams (Fig. 4), which can be used as secondary raw materials for different industrial processes. These side streams can be grouped into five categories, including bark, cellulose chips (C-chips), planer chips, sawdust and uneven dry chips. $\mathrm{C}$-chips are directly delivered to the pulping industries, while the other categories are mostly used for energy generation, either at sawmill or delivered to municipal incineration plants.

\section{Pulp and Paper Mills}

Sweden is dominant within the global pulp and paper market, as it is the world's second largest exporter of pulp and paper products. Thus, the pulp and paper sector is of key importance for the Swedish economy, and provides employment for more than 120,000 people including those indirectly involved in services, maintenance and other related activities. However, the production volumes have been shrinking since 2000 and are today at historically low levels [34]. There are several reasons that have contributed to this result, mainly the rising market competition and to a lesser extent, the reduced production of newspaper due to the digitalization of the media market. Since the Swedish pulp and paper industries are more focused in packaging products and are less specialized in newspaper production, the total production has only reduced by $12 \%$ over the last ten years [35]. It should not be forgotten that the pulp and paper industry is very conservative and it is more focused on protecting existing business structures [36]. Therefore, the needed transition towards biorefinery concepts to provide access in new value chains and transformations to more efficient milling technologies are slower than they should be to maintain competitiveness [37-39]. This fact has to be attributed to the high capital and energy intensive character of the sector along with the close dependence on energy prices, which make it difficult to realize industrial changes in a short timeframe [40].

A thorough overview of inventories of the Swedish pulp and paper sector during the past 20 years has been published by the Swedish Forest Industries Federation [16]. During this period (1994-2018), Sweden's pulp production expanded from 3.3 to 4.3 million tons, while paper production expanded from 9.2 to 10.3 million tons. Bleached sulfate softwood was the major product in 2018 (68\%) followed by other chemical pulp (22\%) and mechanical and semi-chemical pulp (10\%) (Fig. 5). The packaging products were the dominant paper products in 2018 (paperboard and packaging with 29\% and corrugated materials with 22\%) (Fig. 6). A continuous increase was
Fig. 5 Sweden's pulp production 2018 [16]

Fig. 6 Sweden's paper production 2018 [16]
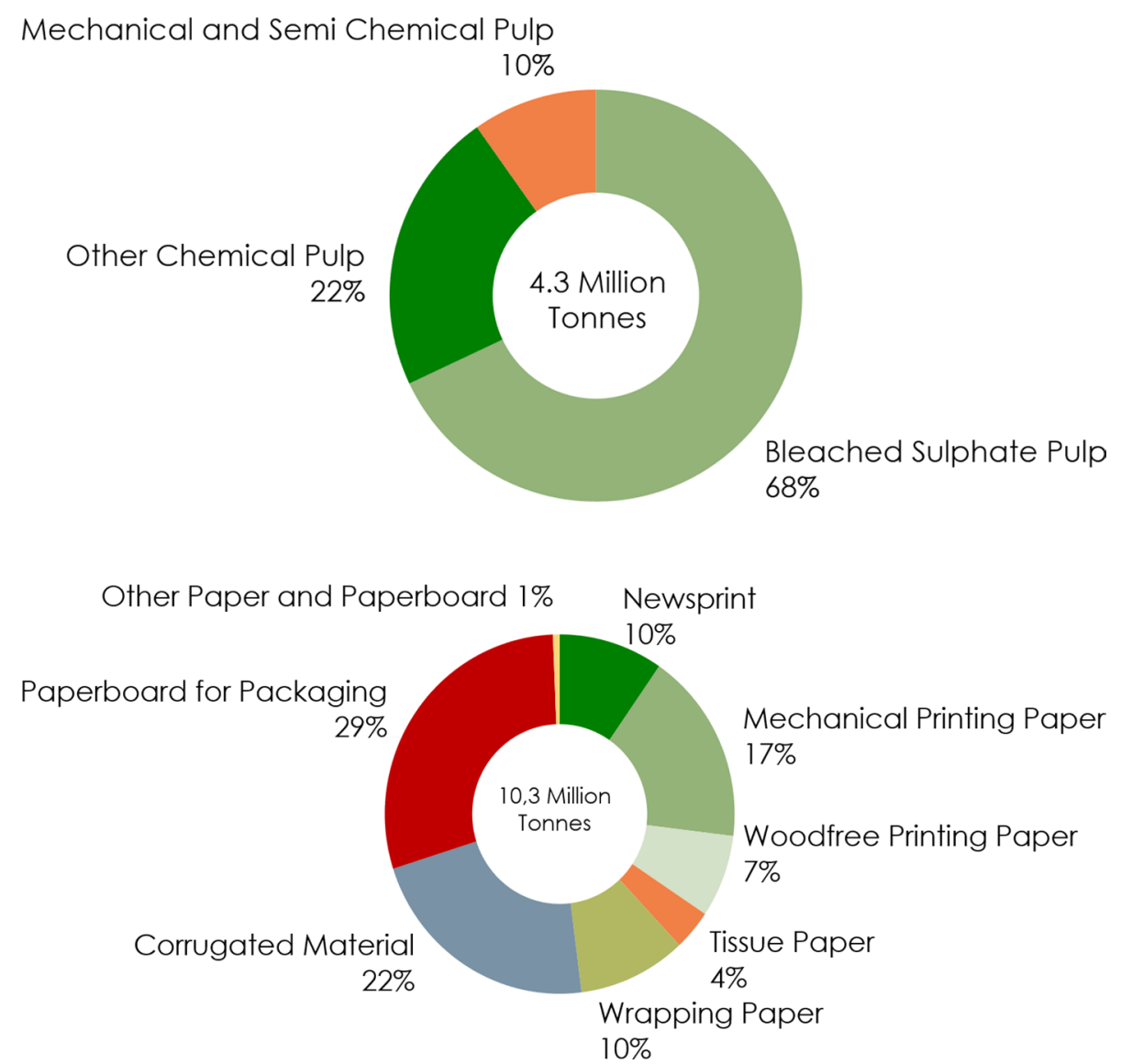
noted for paper production, despite an interruption in 2013 due to closures of paper mills. For both pulp and paper production, the domestic deliveries have remained broadly unchanged, and most of the growth in capacity has being used for exports.

Overall, the pulp and paper exports increased from 2.9 to 3.6 million tons and from 7.7 to 9.2 million tons, respectively for the years 1994 and 2018 [16]. The major part of these exports was to EU countries ( $76 \%$ for both cases, e.g. 2.4 million tons pulp and 6.3 million tons paper and paperboard products). Bleached sulfate softwood pulp had the highest market share of $84 \%$ in 2018 while the export share of the different paper and paperboard products ranged from 61 to $96 \%$. The other pulp types (mechanical and semi-chemical pulp, other chemical pulp) are dedicated to domestic use, and their export share was very low (10-16\%). The production of chemical and semi-chemical wood pulp in Europe has been fairly stable during the last five years. In the European market, exports of chemical wood pulp was 14.6 million tons in 2018 compared to 14.2 million tons in 2017, whilst imports decreased from 18.2 million tons in 2017 to 17.8 million tons in 2018 [26]. More details on pulp and paper production, including exports and imports in

Table 2 Production, export and import of market pulp in Sweden compared with Europe [32]

\begin{tabular}{|c|c|c|c|c|c|c|c|}
\hline Pulp type & Value (tons) & Region & 2014 & 2015 & 2016 & 2017 & 2018 \\
\hline \multirow[t]{6}{*}{ Chemical wood pulp } & \multirow[t]{2}{*}{ Production } & Sweden & $7,736,025$ & $7,788,999$ & $8,009,011$ & $8,248,125$ & $8,112,323$ \\
\hline & & Europe & $31,081,263$ & $31,025,705$ & $31,025,705$ & $33,058,774$ & $33,288,221$ \\
\hline & \multirow[t]{2}{*}{ Export } & Sweden & $2,675,026$ & $2,693,248$ & $2,638,951$ & $2,675,026$ & $2,867,323$ \\
\hline & & Europe & $13,233,566$ & $12,805,494$ & $13,968,964$ & $14,186,430$ & $14,554,232$ \\
\hline & \multirow[t]{2}{*}{ Import } & Sweden & 338,130 & 352,514 & 365,943 & 340,739 & 322,019 \\
\hline & & Europe & $17,186,705$ & $17,387,275$ & $18,005,863$ & $18,156,442$ & $17,829,169$ \\
\hline \multirow[t]{6}{*}{ Dissolving wood pulp } & \multirow[t]{2}{*}{ Production } & Sweden & 540,000 & 535,000 & 532,750 & 503,000 & 478,000 \\
\hline & & Europe & $1,873,286$ & $1,839,910$ & $2,110,222$ & $2,154,215$ & $2,142,662$ \\
\hline & \multirow[t]{2}{*}{ Export } & Sweden & 532,450 & 360,672 & 272,776 & 287,400 & 287,000 \\
\hline & & Europe & $1,532,767$ & $1,556,315$ & $1,246,348$ & $1,332,556$ & $1,287,383$ \\
\hline & \multirow[t]{2}{*}{ Import } & Sweden & 16,170 & 13,431 & 14,219 & 22,746 & 21,592 \\
\hline & & Europe & 932,219 & 780,586 & 743,176 & 750,904 & 716,539 \\
\hline \multirow[t]{6}{*}{ Mechanical wood pulp } & \multirow[t]{2}{*}{ Production } & Sweden & $3,010,346$ & $3,050,118$ & $3,033,473$ & $3,142,601$ & $3,142,601$ \\
\hline & & Europe & $10,656,919$ & $11,178,108$ & $11,587,485$ & $11,554,798$ & $11,554,798$ \\
\hline & \multirow[t]{2}{*}{ Export } & Sweden & 31,240 & 55,716 & 60,230 & 68,204 & 68,204 \\
\hline & & Europe & 387,997 & 351,343 & 285,463 & 331,387 & 331,387 \\
\hline & \multirow[t]{2}{*}{ Import } & Sweden & 10,260 & 10,513 & 18,910 & 24,747 & 24,747 \\
\hline & & Europe & 247,247 & 277,801 & 236,587 & 275,818 & 275,818 \\
\hline \multirow[t]{6}{*}{ Pulp from fibers other than wood } & \multirow[t]{2}{*}{ Production } & Sweden & 0 & 0 & 0 & 0 & 0 \\
\hline & & Europe & $1,393,252$ & $1,349,084$ & 926,954 & 706,551 & 645,752 \\
\hline & \multirow[t]{2}{*}{ Export } & Sweden & 90 & 28 & 0 & 19 & 91 \\
\hline & & Europe & 227,212 & 159,343 & 140,367 & 134,472 & 113,659 \\
\hline & \multirow[t]{2}{*}{ Import } & Sweden & 12,990 & 14,000 & 13,595 & 13,349 & 14,517 \\
\hline & & Europe & 240,611 & 180,551 & 166,838 & 156,565 & 157,231 \\
\hline \multirow[t]{6}{*}{ Recovered fiber pulp } & \multirow[t]{2}{*}{ Production } & Sweden & 250,000 & 250,000 & 250,000 & 250,000 & 250,000 \\
\hline & & Europe & $23,898,360$ & $24,665,786$ & $21,691,489$ & $21,844,094$ & $22,124,320$ \\
\hline & \multirow[t]{2}{*}{ Export } & Sweden & 90 & 163 & 561 & 802 & 169 \\
\hline & & Europe & 134,400 & 153,109 & 148,871 & 147,754 & 195,787 \\
\hline & \multirow[t]{2}{*}{ Import } & Sweden & 4450 & 3215 & 3592 & 3762 & 5010 \\
\hline & & Europe & 177,214 & 79,150 & 88,511 & 98,900 & 113,204 \\
\hline \multirow[t]{6}{*}{ Semi-chemical wood pulp } & \multirow[t]{2}{*}{ Production } & Sweden & 244,654 & 247,882 & 246,527 & 255,399 & 255,399 \\
\hline & & Europe & 244,654 & $1,824,645$ & $1,921,587$ & $1,898,882$ & $1,898,882$ \\
\hline & \multirow[t]{2}{*}{ Export } & Sweden & $1,987,949$ & 207,276 & 279,029 & 315,972 & 315,972 \\
\hline & & Europe & 215,290 & 859,661 & $1,083,419$ & $1,187,336$ & $1,187,336$ \\
\hline & \multirow[t]{2}{*}{ Import } & Sweden & 832,435 & 18,311 & 137,483 & 179,913 & 179,913 \\
\hline & & Europe & 26,690 & 579,159 & 676,495 & 753,013 & 753,013 \\
\hline
\end{tabular}


Table 3 Production, export and import of paper and paper based products in Sweden compared with Europe [32]

\begin{tabular}{|c|c|c|c|c|c|c|c|}
\hline Paper and paper products & Value (tons) & Region & 2014 & 2015 & 2016 & 2017 & 2018 \\
\hline \multirow[t]{6}{*}{ Carton board } & \multirow[t]{2}{*}{ Production } & Sweden & $2,609,000$ & $2,620,000$ & $2,867,000$ & $2,954,000$ & $2,972,000$ \\
\hline & & Europe & $10,767,202$ & $11,310,452$ & $11,800,368$ & $12,027,475$ & $12,079,603$ \\
\hline & \multirow[t]{2}{*}{ Export } & Sweden & $2,480,000$ & $2,690,027$ & $2,884,209$ & $3,117,000$ & $2,940,000$ \\
\hline & & Europe & $9,601,455$ & $10,164,015$ & $10,530,765$ & $11,445,710$ & $11,620,858$ \\
\hline & \multirow[t]{2}{*}{ Import } & Sweden & 124,790 & 137,008 & 142,630 & 119,540 & 99,472 \\
\hline & & Europe & $7,474,874$ & $7,656,377$ & $7,917,173$ & $8,122,485$ & $8,262,956$ \\
\hline \multirow[t]{6}{*}{ Printing and writing papers } & \multirow[t]{2}{*}{ Production } & Sweden & $3,067,000$ & $3,067,000$ & $2,593,999$ & $2,577,010$ & $2,509,999$ \\
\hline & & Europe & $31,691,061$ & $31,691,061$ & $29,215,140$ & $29,065,773$ & $28,457,260$ \\
\hline & \multirow[t]{2}{*}{ Export } & Sweden & $3,121,050$ & $3,121,050$ & $2,683,309$ & $2,441,000$ & $2,331,000$ \\
\hline & & Europe & $27,709,445$ & $27,709,445$ & $26,396,982$ & $25,892,746$ & $25,598,018$ \\
\hline & \multirow[t]{2}{*}{ Import } & Sweden & 281,750 & 281,750 & 269,197 & 325,186 & 275,725 \\
\hline & & Europe & $20,829,681$ & $20,829,681$ & $19,902,406$ & $19,642,514$ & $19,132,049$ \\
\hline \multirow[t]{6}{*}{ Recovered paper } & \multirow[t]{2}{*}{ Production } & Sweden & $1,161,000$ & $1,210,000$ & $1,159,000$ & $1,155,000$ & $1,148,000$ \\
\hline & & Europe & $60,155,113$ & $60,619,063$ & $60,945,979$ & $60,992,982$ & $60,609,628$ \\
\hline & \multirow[t]{2}{*}{ Export } & Sweden & 453,030 & 466,672 & 501,434 & 452,063 & 430,773 \\
\hline & & Europe & $23,068,810$ & $24,322,200$ & $24,749,439$ & $25,244,565$ & $24,453,911$ \\
\hline & \multirow[t]{2}{*}{ Import } & Sweden & 700,500 & 604,254 & 634,919 & 579,520 & 702,170 \\
\hline & & Europe & $14,490,314$ & $14,922,913$ & $15,469,982$ & $16,214,392$ & $16,086,023$ \\
\hline \multirow[t]{6}{*}{ Wrapping papers } & \multirow[t]{2}{*}{ Production } & Sweden & $1,010,000$ & $1,060,000$ & $1,033,000$ & $1,038,000$ & $1,014,000$ \\
\hline & & Europe & $5,486,303$ & $5,745,029$ & $5,666,116$ & $5,800,048$ & $5,850,015$ \\
\hline & \multirow[t]{2}{*}{ Export } & Sweden & 962,000 & $1,139,281$ & $1,059,000$ & 940,000 & 914,000 \\
\hline & & Europe & $5,135,892$ & $5,540,751$ & $5,651,348$ & $5,635,237$ & $5,958,016$ \\
\hline & \multirow[t]{2}{*}{ Import } & Sweden & 103,450 & 79,367 & 55,723 & 50,667 & 50,580 \\
\hline & & Europe & $4,212,649$ & $4,265,264$ & $4,355,937$ & $4,599,236$ & $4,752,655$ \\
\hline \multirow{6}{*}{$\begin{array}{l}\text { Other paper and paperboard } \\
\text { (not elsewhere specified) }\end{array}$} & \multirow[t]{2}{*}{ Production } & Sweden & 60,000 & 61,000 & 53,000 & 71,000 & 63,000 \\
\hline & & Europe & $3,953,889$ & $3,939,889$ & $4,091,309$ & $4,531,730$ & $4,549,772$ \\
\hline & \multirow[t]{2}{*}{ Export } & Sweden & 15,040 & 18,213 & 18,233 & 2,614 & 2,355 \\
\hline & & Europe & 636,120 & 819,749 & 849,157 & 866,745 & 716,252 \\
\hline & \multirow[t]{2}{*}{ Import } & Sweden & 6,030 & 7,478 & 27,011 & 2,236 & 1,502 \\
\hline & & Europe & 771,765 & 779,254 & 915,045 & 849,748 & 828,689 \\
\hline \multirow[t]{6}{*}{ Newsprint } & \multirow[t]{2}{*}{ Production } & Sweden & $1,258,000$ & $1,197,000$ & $1,016,000$ & $1,011,000$ & 977,000 \\
\hline & & Europe & $9,174,552$ & $8,444,360$ & $8,305,841$ & $7,831,952$ & $7,584,686$ \\
\hline & \multirow[t]{2}{*}{ Export } & Sweden & 909,670 & 889,877 & 768,735 & 846,000 & 790,000 \\
\hline & & Europe & $6,156,845$ & $5,838,463$ & $5,771,530$ & $5,743,283$ & $5,389,206$ \\
\hline & \multirow[t]{2}{*}{ Import } & Sweden & 32,230 & 25,658 & 54,035 & 58,042 & 51,702 \\
\hline & & Europe & $4,505,790$ & $4,302,995$ & $4,272,432$ & $4,079,995$ & $3,856,586$ \\
\hline
\end{tabular}

Sweden compared with Europe between 2014 and 2018 can be seen in Tables 2 and 3 .

Regarding the structure of pulp production, the 5 largest mills (out of the 18 operating pulp mills) accounted for 57\% of the capacity (i.e. 2.3 million tons) in 2018, and mainly produced sulfate pulp. The total capacity for pulp was 4.3 million tons, while Sweden's total pulp capacity for the year 2018 was 12 million tons [16]. For paper production, the 14 largest mills (out of a total of 38 ) accounted for $54 \%$ of the capacity (i.e. 6.2 million tons) in 2018. The total paper capacity for 2018 was 11.3 million tons. In terms of mill size, the " 400,000 tons plus" category typically accounted for those that produce newsprint, writing and printing paper, paper for the production of corrugated board and packaging paper. Of the " 100,000 tons and under" category, half the mills produce soft tissue paper, but the rest also includes mills that produce packaging paper. There are a few large actors dominating the sector, with the four largest companies Holmen, SCA, Södra and Stora Enso together representing $64 \%$ of the production of pulp and $60 \%$ of paper in Sweden.

The pulp and paper industries in Sweden rely on local forest based raw materials. The total stocks of coniferous logs, pulpwood and wood chips were estimated to about 6.4 million $\mathrm{m}^{3} \mathrm{f} u b$ (cubic metre solid volume excl. bark) in 
2017. This is a decline by $19 \%$ compared with 2016 due to a decrease of $34 \%$ of all assortments of pulpwood stocks. The total stocks of pulpwood amounted to 2.9 million $\mathrm{m}^{3} \mathrm{f}$ $\mathrm{ub}$ in 2016 , of which 1.88 million $\mathrm{m}^{3} \mathrm{f}$ ub were mixed coniferous, 0.47 million $\mathrm{m}^{3} \mathrm{f}$ ub spruce and 0.9 million $\mathrm{m}^{3} \mathrm{f} u b$ broadleaved species [16]. The stock volumes of wood chips ( 0.8 million $\mathrm{m}^{3} \mathrm{f} \mathrm{ub}$ ) were also decreased by $10 \%$ in 2017 compared to 2016. According to the data, paper production is mainly based on chemical pulp (50\%), then mechanical and semi-chemical pulp (28\%), recovered paper pulp (9\%), and filler and pigments (13\%). The sustainability of paper companies in Sweden is partly due to paper recovery. In 2018, approximately 1.2 million tons of different recovered paper grades (e.g. newspapers and periodicals, corrugated containers, high grades, other) were used in the production of different paper products [16]. Imports of recovered paper have decreased while exports have slightly increased since 2010 , but the volumes are low for both cases and below 0.5 million tons. However, paper recycling has almost reached its limits in Sweden and it was $80 \%$ for packaging, $95 \%$ for newspapers and 65\% for office paper in 2017 [16].

The competitiveness of the Swedish pulp and paper sector has been boosted historically by a combination of favoring factors, such as low energy prices, skilled work force, access to high quality forest raw materials, efficient transportation infrastructure and efficient product and process development [41, 42]. Pulp and paper companies in Sweden are pioneers in efficiency as the recovery of waste (defined as recovery of material and energy plus other utilization as percentage of total amount of waste) from production processes in the period 2001-2018 has been constantly around or more than $90 \%$. Also, since the beginning of 1980 s, pulp and paper mills have reduced the organic materials they release into the water system by $90 \%$ and have reduced the sulfur compounds they release into the air by $98 \%[43,44]$. However, the increased competition from the global market along with regulations on pollutants and emissions, and increasing electricity prices have forced the industry to intensify its sustainability efforts in the last twenty years, mainly towards investments in energy efficiency, and production of biofuels and other renewable electricity [45-47]. As a result, the pulp and paper mills are today climate neutral and the sector is one of the major renewable energy producers in Sweden [48, 49]. The Swedish pulp and paper industry has the lowest carbon emissions per ton of product in the world followed by Norway, Finland and Canada [50]. This is acknowledgment to the environmental legislation and Sweden's energy and climate policy [40].

\section{Construction and Furniture}

The construction sector (wood panels, solid wood, etc.), represented by the building and housing industry, consumes about $70 \%$ of volume of sawn timber annually in Sweden, in the form of framework material, moulded construction timber, form work, windows, stairs, impregnated wood, etc. The joinery and furniture industries consume a much smaller portion (ca. 20\%) of volume of sawn timber but the added value of this portion of refined wood products is $15-20$ times higher [16]. Given that $70 \%$ of the sawn volume is exported, it is thus evident that the value of the products going to the construction sector is currently very low and the manufacture within the country of solid wood products with a high added value is also low. Today, there is an increasing production of timber houses in Sweden as well as an increased degree of renovation of old buildings, due to a combination of favoring factors such as modern building regulations, allowing for multi-storey timber buildings, lower costs of building with wood compared to constructions using other materials, growing environmental awareness and governmental policies [51]. Currently Kulturhus, a 19-storey cultural centre and hotel is being built in Skellefteå by the Swedish firm White Arkitekter. The 76 metres structure is proposed to be the tallest wooden building in the Nordic countries [52]. White Arkitekter plans to realize the building using two types of hybrid construction system, rather than an entirely timber frame. The first brings together wood and steel, while the other pairs wooden modules with concrete slabs [52].

In detail, timber houses represent around $90 \%$ of newly constructed single-family housing [53, 54]. This trend is expected to increase the need of new wooden furniture and joinery products and to create opportunities for increased cooperation between the building industry and the furniture and joinery industries. The machining industry in Sweden would be forced to satisfy the modern building processes that require more refined timber in the form of components and systems in order to achieve a high productivity [22].

The Swedish timber house industry in 2017 consisted of 527 companies with 6062 employees, 32 of which accounted for $75 \%$ of the market share of assembly-ready houses [54]. The production value was around SEK 15.0 billion in 2016. The total exports of prefabricated timber houses declined by $21 \%$ and amounted to SEK 575 million in $2016 \mathrm{com}$ pared to 2015 , and there was an increase of imports by $11 \%$. Besides sawn timber, the construction, furniture and joinery industries are supplied with materials from the wood-based panel industry. According to Statistics Sweden, this industry together with the parquet industry consisted of 74 companies with 1530 employees in 2015. The output accounted for approximately SEK 3.9 billion and value added amounted to SEK 1.1 billion. There was an overall rise in production of wood-based panels by $8 \%$ to $626,000 \mathrm{~m}^{3}$ in 2015 compared to 2014. Exports of wood-based panels such as HDF/MDF and plywood declined while imports increased from 2014 to 2018. In contrast, the export and import of wood based 
panels in the European market increased during this period. The Swedish furniture industry in 2016 comprised 2290 companies, of which 1445 are companies with null employees. Total numbers of employees were 13,376. In 2015 the total production value of furniture amounted to SEK 24.5 billion. Exports of furniture rose by $1 \%$ to SEK 15.9 billion in 2016 compared to 2015. Norway is the main market of export, whilst other EU countries are also important. Total imports of furniture increased by $3 \%$ to SEK 16.6 billion in 2016 compared to 2015 [55]. Swedish imports were mainly from Poland, Norway and the EU countries. More details on the production, exports and imports of the Swedish wood-based panel industry compared with Europe in the years 2014 to 2018 can be seen in Table 4 .

In recent years, the cost of wood raw material, energy and chemicals has negatively affected the wood-based panel industry in Sweden. The industry will continue to face growing competition for wood from the renewable energy sector [51]. Much of Sweden is facing a housing shortage, primarily in its metropolitan regions. Sweden has one of the highest levels of urbanization in the EU. Housing construction has continued to increase, but remains well below new construction needs. To meet this demand, Swedish woodbased panel industries have continued to invest and develop new wood and cellulose-based products, such as bioplastics
Table 4 Production, export and import of wood-based panels in Sweden compared with Europe [32]

\begin{tabular}{|c|c|c|c|c|c|c|c|}
\hline Wood based panels & Value $\left(\mathrm{m}^{3}\right)$ & Region & 2014 & 2015 & 2016 & 2017 & 2018 \\
\hline \multirow[t]{6}{*}{ Hardboard } & \multirow[t]{2}{*}{ Production } & Sweden & 0 & 0 & 0 & 0 & 0 \\
\hline & & Europe & $3,950,939$ & $3,826,589$ & $4,003,920$ & $4,147,215$ & $4,085,855$ \\
\hline & \multirow[t]{2}{*}{ Export } & Sweden & 3160 & 5154 & 4506 & 4088 & 4502 \\
\hline & & Europe & $3,025,398$ & $2,998,853$ & $2,983,668$ & $3,137,478$ & $3,077,012$ \\
\hline & \multirow[t]{2}{*}{ Import } & Sweden & 74,110 & 75,912 & 75,724 & 75,767 & 72,571 \\
\hline & & Europe & $2,288,632$ & $2,296,073$ & $2,447,583$ & $2,646,395$ & $2,777,011$ \\
\hline \multirow[t]{6}{*}{$\mathrm{MDF} / \mathrm{HDF}$} & \multirow[t]{2}{*}{ Production } & Sweden & 0 & 0 & 0 & 0 & 0 \\
\hline & & Europe & $13,366,319$ & $14,912,175$ & $16,110,190$ & $17,366,139$ & $17,825,338$ \\
\hline & \multirow[t]{2}{*}{ Export } & Sweden & 58,330 & 47,099 & 42,182 & 39,227 & 39,176 \\
\hline & & Europe & $7,935,065$ & $8,447,006$ & $8,963,345$ & $9,554,343$ & $9,772,434$ \\
\hline & \multirow[t]{2}{*}{ Import } & Sweden & 222,990 & 225,296 & 218,831 & 210,684 & 225,222 \\
\hline & & Europe & $6,557,705$ & $6,325,566$ & $6,457,142$ & $6,837,703$ & $7,349,227$ \\
\hline \multirow[t]{6}{*}{ OSB } & \multirow[t]{2}{*}{ Production } & Sweden & 0 & 0 & 0 & 0 & 0 \\
\hline & & Europe & $5,972,507$ & $7,292,078$ & $8,498,002$ & $9,009,650$ & $9,379,072$ \\
\hline & \multirow[t]{2}{*}{ Export } & Sweden & 1230 & 1645 & 3959 & 5277 & 5676 \\
\hline & & Europe & $3,743,499$ & $4,048,906$ & $4,780,731$ & $5,265,979$ & $5,126,208$ \\
\hline & \multirow[t]{2}{*}{ Import } & Sweden & 122,370 & 123,289 & 158,064 & 158,032 & 173,066 \\
\hline & & Europe & $3,335,765$ & $3,292,965$ & $3,528,064$ & $3,985,551$ & $3,973,343$ \\
\hline \multirow[t]{6}{*}{ Particleboard } & \multirow[t]{2}{*}{ Production } & Sweden & 494,000 & 600,000 & 550,000 & 550,000 & 550,000 \\
\hline & & Europe & $41,221,423$ & $42,141,954$ & $42,417,405$ & $44,000,160$ & $45,036,532$ \\
\hline & \multirow[t]{2}{*}{ Export } & Sweden & 88,700 & 60,031 & 80,719 & 97,283 & 88,843 \\
\hline & & Europe & $14,308,105$ & $14,684,844$ & $15,363,200$ & $16,428,707$ & $15,950,745$ \\
\hline & \multirow[t]{2}{*}{ Import } & Sweden & 427,640 & 427,489 & 413,952 & 456,558 & 464,338 \\
\hline & & Europe & $11,651,703$ & $11,812,064$ & $12,352,278$ & $13,159,674$ & $13,173,419$ \\
\hline \multirow[t]{6}{*}{ Plywood } & \multirow[t]{2}{*}{ Production } & Sweden & 82,000 & 60,000 & 60,000 & 85,000 & 85,000 \\
\hline & & Europe & $8,279,646$ & $8,375,523$ & $8,772,743$ & $9,786,426$ & $9,823,923$ \\
\hline & \multirow[t]{2}{*}{ Export } & Sweden & 31,160 & 24,447 & 22,470 & 21,415 & 22,927 \\
\hline & & Europe & $6,248,770$ & $6,517,498$ & $7,088,530$ & $7,411,564$ & $7,621,096$ \\
\hline & \multirow[t]{2}{*}{ Import } & Sweden & 162,910 & 149,650 & 174,720 & 206,485 & 223,054 \\
\hline & & Europe & $7,144,216$ & $7,180,879$ & $7,503,526$ & $7,774,507$ & $8,071,428$ \\
\hline \multirow[t]{6}{*}{ Other fiberboard } & \multirow[t]{2}{*}{ Production } & Sweden & 0 & 0 & 0 & 0 & 0 \\
\hline & & Europe & $3,009,481$ & $2,902,253$ & $3,222,878$ & $3,679,957$ & $3,713,269$ \\
\hline & \multirow[t]{2}{*}{ Export } & Sweden & 8950 & 4092 & 9537 & 14,988 & 11,768 \\
\hline & & Europe & $1,747,560$ & $1,783,779$ & $1,743,605$ & $1,660,058$ & $1,538,636$ \\
\hline & \multirow[t]{2}{*}{ Import } & Sweden & 33,260 & 29,973 & 33,834 & 40,476 & 36,652 \\
\hline & & Europe & $1,527,938$ & $1,586,506$ & $1,794,968$ & $1,948,315$ & $2,019,047$ \\
\hline
\end{tabular}


and biocomposites. There has been significant investment in research and development by the big players in the industries. For instance, Martinsons opened a new CLT line in 2017. Södra is also investing in its first CLT facility at Värö with an initial production of $5000 \mathrm{~m}^{3}$ from 2019 onwards. Stora Enso has also invested in production of CLT in Gruvön to start production in 2019. In addition, Stora Enso recently started a new biocomposite plant which produces DuraSense ${ }^{\mathrm{TM}}$. This product is a wood-fibre biocomposite that offers the mouldability of plastics and the strength and sustainability of wood. The development of the product results to approximately $80 \%$ reduction in carbon dioxide footprint over conventional products. These developments indicate that there is a strong trend in increased wood processing with the manufacturing of building elements.

\section{Biorefineries}

The use of biomass as raw materials for biochemical production has been motivated by realizing a reduction in fossil carbon dioxide emissions, ensuring security in energy supply, and a desire to revitalize rural areas [56]. The Swedish biorefinery sector has been expanding in products manufacturing over the last decade. The recent climb in fossil oil prices, customer preference for eco-friendly products, population growth and limited supplies of non-renewable resources have opened up new channels of opportunity for biobased products and polymers [57]. One of Europe's premier biorefineries based on wood as a raw materials is located in Domsjö, Sweden, which utilizes renewable wood raw materials and converts them into various green products for a diverse range of uses [58]. These products are then refined by secondary biorefinery companies, which are subsequently used to produce textiles, medicine, foodstuffs and other consumable materials. The Biorefinery Demo Plant in Örnsköldsvik, Sweden, has all the necessary competence and equipment to convert biomass into various final products, e.g. carbohydrates, lignin, proteins, enzymes, chemicals, material and ethanol [59]. There are several other small and large biorefinery companies in Sweden with dedicated and integrated production facilities. These companies are active in research and development, product development, consulting or manufacturing within the included business segments of the chemical industry, with a total of about 33,000 employees. Today, the chemical industry is providing modern materials and enabling technical solutions in virtually all sectors of the economy [60].

There is a growing demand for biochemical products in Sweden but more biorefineries will only have a small effect on the availability and pricing of wood products and feedstock [61]. The replacement of fossil oil with biomass as raw material for fuel and chemical production has been the driving force for the development of biorefinery complexes
[56]. However, the cost of biochemical production exceeds that of petrochemical production. As a consequence, the new biobased products must be proven to perform at least as good as the conventional products and have a lower environmental impact [57]. In biorefining, different biomass materials can be converted to different classes of biochemical products through jointly applied conversion technologies. The Swedish biorefinery concept focuses on utilizing renewable forest biomass as much as possible for producing a variety of products, i.e. making more out of the tree [58]. Forest residues are also important sources of raw materials for the biochemical industry. Forest residues consists not only of cellulose and hemicellulose, which can be fermented to useful molecules, but also of lignin. One challenge is therefore to find ways of using not only the cellulose and hemicellulose, but also the lignin to realize valuable compounds from the biorefinery [62]. There is a potential to significantly increase the use of forest residues in Sweden, compared to current levels. However, a certain share must be recycled to the forest to avoid degradation of soil organic carbon and nutrients [62]. The bark of stem and foliage are the main carriers of micro nutrients while the foliage is the main carrier of macro nutrients [63]. These are vital ecosystem residues and should meet certain ecological restrictions in order to achieve sustainable biomass production and utilization as a renewable material [63]. Ecological balance and ecosystem productivity depend on the composition and the amount of extracted biomass. Therefore, the environmental sustainability of using forest residues as raw material in a biorefinery is still under consideration.

Swedish biochemical industries accounted for approximately $17 \%$ of Swedish exports (including pharmaceutical and mineral oil products). The main biobased products are obtained from biomass processing into basic products like starch, oil, and cellulose. In addition, chemicals such as lactic acid and amino acids are produced and used in the food industry. Other commercial biobased products include adhesives, cleaning compounds, detergents, dielectric fluids, dyes, hydraulic fluids, inks, lubricants, packaging materials, paints and coatings, paper and box board, plastic fillers, polymers, solvents, and sorbents [56]. Currently, most companies that have integrated facilities for biochemical production focus on development and manufacturing of biofuels. Domsjö Fabriker, which produces celluloses used for manufacturing textiles (viscose) is Sweden's largest producer of biogas. Some of the companies develop and manufacture chemicals or materials (e.g., Arizona Chemicals and Organoclic) and some focus on process development (e.g., Bioendev and the process for torrefaction and Värmlandsmetanol and the process for producing methanol from wood) [60].

The Swedish pharmaceutical products and reagents companies account for almost half of the employment in 
the chemical industry, but only contain about $20 \%$ of the number of companies. The chemical industry is dominated by a limited number of large companies. More than half of the companies produce chemical products, yet these companies are generally rather small and their combined share of employees is only about 25\% [60]. Regarding the structure, the Swedish biochemical industry is characterized by a small number of large companies and corporate groups, yet roughly corresponds to $80 \%$ of total employment in 2014. Compared to previous years, there has been a slight change mainly due to the fact that the largest companies have decreased their share of employment more than the industry average [60]. Companies in the business segment consist of larger exporting companies (Lantmännen Agroetanol, SEKAB, Arizona Chemicals, Domsjö Fabriker, etc.) and smaller companies focused on development and demonstration of biorefinery technologies (e.g., Taurus Energy, Lignoboost Demo). Most of the companies engage in research and development and/or product development, usually in cooperation with other companies [60].

\section{Environmental Considerations}

Due to the current opinion that the provision of wood as raw material does not cause high GHG-emissions, wood and wood products are commonly claimed as carbon neutral. Usually, the carbon dioxide that is released when trees are felled is absorbed by surrounding forests, which makes the wood material climate neutral [64]. This opinion is manifested with the consideration that all removed biomass from sustainably managed forests will be sequestered again in the future [65]. Similarly, an increase in tree biomass means an increase in carbon sequestration. Due to the absorption of carbon dioxide, forests are generally regarded as carbon dioxide sinks. They can also be regarded as carbon dioxide neutral, since the carbon dioxide absorbed from the start of their life cycle is released when the forests are harvested [64]. Wood products from forest biomass will continue to act as significant carbon sinks, which can be extended until the wood decays or is burned. It also implies that an increased use of wood will help to counteract the release of carbon dioxide at felling [64]. However, the issue of carbon neutrality remains a controversial point [66] and may be further confused through issues such as land use changes [67]. Carbon neutrality can play a significant role in GHG emissions, as has been identified by the Intergovernmental Panel on Climate Change (IPCC) [68], given that levels of atmospheric GHGs are at their highest for some 800,000 years [69]. Sustainable biomass utilization is beneficial for global climate due to carbon neutrality and issues resulting from emissions [70]. Carbon accounting allows for tracking of carbon between the environment and products and resulting carbon trading has been applied within the bioenergy sector [69]. The environment could also be referred to as a socialecological system $[71,72]$ as "there are neither natural or pristine systems without people nor social systems without nature. Social and ecological systems are not just linked but truly interconnected and co-evolving across spatial and temporal scales" [73]. The interconnection of ecological and social systems is also present in life cycle impact assessment (LCIA) methodology, where the areas of protection in endpoint-modelling typically cover both ecological and social values.

To meet the challenges that climate change presents, there has to be a shift to sustainable biomass production and increased interest in promoting a circular bioeconomy. Sustainable biomass production from forest ecosystems is affected by the terrain, ecological parameters, forest management, and the landscape's heterogeneity and conservation [70]. The spatial approach using Geographic Information System and Remote Sensing assists the creation of ecological and sustainable framework in biomass harvesting procedures from forest ecosystems. This opens new horizons for research in spatial limitations which have to be considered to ensure the preservation of an ecosystem [55]. The positive relationship between sustainable forest management, growth and carbon dioxide uptake can be illustrated by developments in Sweden over the last 100 years, where silviculture has been focused on long-term sustainable production [64]. Sustainable forest biomass utilization needs to be combined with silviculture through effective forest management in order to achieve the environmental goals [70]. With current management practices, the Swedish forest will continue to provide an annual climate benefit that corresponds to a 60 million ton reduction in carbon dioxide emissions. Most of this climate gains will come from replacing fossil fuel with renewable forest biomass. The positive climate mitigation effect is estimated to be greater than the temporary gains that could be achieved by reducing felling in order to build up the carbon sinks in forests and forest soil [64].

There has been an upsurge in the use of timber in construction through the development of advanced construction products. The use of timber in modern buildings has been shown to benefit from encapsulated carbon within the building structure, effectively locking it in use for decades. This has been effectively shown in a range of recently constructed buildings. The replacement of conventional building materials such as concrete, metal and other fossil-derived materials with wood products where applicable, will result in greater carbon gains [64]. For every cubic meter of timber harvested for use as a wood product, approximately $470 \mathrm{~kg}$ of carbon dioxide emissions is eliminated. 


\section{Conclusion and Future Prospects}

From the outset, it is evident that the available biomass in Sweden can be utilized to provide a sustainable supply of materials (i.e. timber, pulp, paper and paper products, chemicals, biocomposites, and other construction materials) for present and future needs. The sustainable management of forest biomass will continue to provide opportunities for economic growth and productivity, as well as promote a carbon neutral bioeconomy. There are a range of business opportunities that can be based on the Swedish forest sector, which can be summarized into the following thematic groups:

- Processing of primary products into solid wood, and its supply into well-established products (e.g. construction, furniture)

- Processing of secondary products, primarily in the pulp and paper industry

- Use of solid timber and residuals within the biorefineries and bioenergy sectors

- Increased extraction of forest residuals within existing markets or meeting new demands

These categories represent the main business areas that can be served by the Swedish forest sector. With increased environmental awareness and the desire to live in a more carbon neutral society, the use of bio-based materials is seen as a means of lowering the human impact on resources. Whilst Sweden has an abundant forest supply, there is a fixed maximum that can be harvested per year in order to maintain a sustainable resource. Therefore, increased demands from each business sector will increase the political strain on the biomass resources, which are dependent upon market forces and associated prices. Forest products are normally allocated on the basis of the users' willingness to pay (and hence prices meeting needs and demands). National economic policies can impact the willingness to pay for specific sectors both positively and negatively depending on the specific policy implemented. This national demand can significantly affect international forest trade and supply. In order to develop a sustainable bioeconomy, several actions need to be considered. These include; establishing policies that can drive transitions into a biobased economy, improving alignment with bioeconomic objectives, establishing competences to address the bioeconomic potential and improving collaborations across sectors.

Acknowledgements Open access funding provided by Linnaeus University. The authors acknowledge funding provided by the Swedish Research Council Formas (Project 942-2016-2, 2017-21) and by the Kamprad Family Foundation (Project Grant No. 20160052, 2017-19). The authors also wish to thank J G Anderssons Söner AB, Linneryd and KSSR, Kalmar for constructive discussions. The involvemnet of
Dennis Jones within this collaborative paper was as a result of a subcontractual agreement with Research Institutes of Sweden (RISE), Stockholm, for which DJ is extemely grateful.

Open Access This article is licensed under a Creative Commons Attribution 4.0 International License, which permits use, sharing, adaptation, distribution and reproduction in any medium or format, as long as you give appropriate credit to the original author(s) and the source, provide a link to the Creative Commons licence, and indicate if changes were made. The images or other third party material in this article are included in the article's Creative Commons licence, unless indicated otherwise in a credit line to the material. If material is not included in the article's Creative Commons licence and your intended use is not permitted by statutory regulation or exceeds the permitted use, you will need to obtain permission directly from the copyright holder. To view a copy of this licence, visit http://creativecommons.org/licenses/by/4.0/.

\section{References}

1. Jonsson R, Blujdea VNB, Fiorese G, Pilli R, Rinaldi F, Baranzelli C, Camia A: Outlook of the European forest-based sector: forest growth, harvest demand, wood-product markets, and forest carbon dynamics implications. IForest SISEF Ital. Soc. Silvic. For. Ecol.; 2018;11:315-328.

2. FTP: A strategic research agenda for innovation, competitiveness and quality of life. Forest Technology Platform FTP Research and Innovation Portal for the SRA. https://www.forestplatform.org/\#!/ pages/6. Accessed 18 Sept 2019

3. NRA: En nationell strategisk forskningsagenda (NRA) för den skogsbaserade näringen i Sverige - EUROFOREST Portal. https ://forestportal.efi.int/view.php?id=812. Accessed 18 Sept 2019

4. Börjesson, P., Gustavsson, L., Christersson, L., Linder, S.: Future production and utilisation of biomass in Sweden: potentials and CO2 mitigation. Biomass Bioenergy. 13, 399-412 (1997)

5. Manolis, E.N., Zagas, T.D., Poravou, C.A., Zagas, D.T.: Biomass assessment for sustainable bioenergy utilization in a Mediterranean forest ecosystem in northwest Greece. Ecol Eng. 91, 537544 (2016)

6. Freppaz, D., Minciardi, R., Robba, M., Rovatti, M., Sacile, R., Taramasso, A.: Optimizing forest biomass exploitation for energy supply at a regional level. Biomass Bioenergy 26, 15-25 (2004)

7. Roberts, J.J., Cassula, A.M., Osvaldo Prado, P., Dias, R.A., Balestieri, J.A.P.: Assessment of dry residual biomass potential for use as alternative energy source in the party of General Pueyrredón. Argentina. Renew. Sustain. Energy Rev. 41, 568-583 (2015)

8. Lundmark, T., Bergh, J., Hofer, P., Lundström, A., Nordin, A., Poudel, B.C., et al.: Potential roles of Swedish forestry in the context of climate change mitigation. Forests MDPI AG 5, 557-578 (2014)

9. Rosvall, O.: Produktionspotentialen är betydligt högre än dagens tillväxt. K Skogs-och Lantbruksakademiens Tidskr. 4, 13-20 (2007)

10. Nilsson, U., Fahlvik, N., Johansson, U., Lundström, A., Rosvall, O.: Simulation of the effect of intensive forest management on forest production in Sweden. Forests. 2, 373-393 (2011)

11. Poudel, B.C., Sathre, R., Bergh, J., Gustavsson, L., Lundström, A., Hyvönen, R.: Potential effects of intensive forestry on biomass production and total carbon balance in north-central Sweden. Environ. Sci. Policy. 15, 106-124 (2012)

12. SLU: The Swedish National Forest Inventory I Externwebben. https://www.slu.se/en/Collaborative-Centres-and-Projects/theswedish-national-forest-inventory/. Accessed 18 Sept 2019 
13. Swedish Forest Agency: Skogsstyrelsen - Swedish Forest Agency. https://www.skogsstyrelsen.se/en/. Accessed 18 Sept 2019

14. Lundström, A., Söderberg, U.: Outline of the Hugin system for long-term forecasts of timber yields and possible cut. In: Proceedeings of the Large-scale forestry scenario models: experiences and requirements (1996)

15. FAO: Trends and current status of the contribution of the forestry sector to national economies. FAO working paper on financing sustainable forest management FSFM/ACC/07. pp. 1-151. Rome. (2004)

16. Swedish Forest Industries Federation: Forest industries. https:// www.forestindustries.se/. Accessed 17 Sept 2019

17. Swedish Forest Industries Federation. Swedish Forest Sector Research Agenda (2017)

18. Chen, D., Yin, L., Wang, H., He, P.: Pyrolysis technologies for municipal solid waste: a review. Waste Manag. 34, 2466-2486 (2014)

19. Milbrandt, A., Overend, R.P.: Survey of Biomass Resource Assessments and Assessment Capabilities in APEC Economies Energy Working Group (2007)

20. SLU: The Swedish National Forest Inventory. https://taxwebb.slu. se/_layouts/15/slu-xlviewer.aspx?source=/\&id=/PowerPivot Gallery EN/Tema_biomassa_eng.xlsx. Accessed 6 Dec 2019

21. Verkerk, P.J., Anttila, P., Eggers, J., Lindner, M., Asikainen, A.: The realisable potential supply of woody biomass from forests in the European Union. For Ecol Manag. 261, 2007-2015 (2011)

22. Sandberg D, Vasiri M, Trischler J, Öhman M. The role of the wood mechanical industry in the Swedish forest industry cluster. Scand. J. For. Res.; 2014. 29 352-9.

23. Palgan, Y.V., McCormick, K.: Biorefineries in Sweden: perspectives on the opportunities, challenges and future. Biofuels Bioprod Biorefining 10, 523-533 (2016)

24. Sveaskog: Sveaskog in brief. https://www.sveaskog.se/en/about -sveaskog/sveaskog-in-brief/ (2019). Accessed 17 Sept 2019

25. Jordbruksstatistisk sammanställning 2018 med data om livsmedel-tabeller: Agricultural statistics 2018 including food statistics - tables. Official ststistics of Sweden. https://www.scb.se/ publication/35150 (2019). Accessed 22 May 2019

26. Lundmark, R., Athanassiadis, D., Wetterlund, E.: Supply assessment of forest biomass: a bottom-up approach for Sweden. Biomass Bioenergy 75, 213-226 (2015)

27. Tamrakar, R.: Sawmilling in Sweden: past, present and future. Initiat. 5, 110-120 (2014)

28. Blomström, M., Kokko, A.: From natural resources to hightech production: the evolution of industrial competitiveness in Sweden and Finland. In: Lederman, D., Maloney, W.F. (eds.) Natural Resources: Neither Curse Nor Destiny, pp. 213-256. DC, The World Bank, Washinton (2007)

29. Roos, A., Flinkman, M., Jäppinen, A., Lönner, G., Warensjö, M.: Identification of value-adding strategies in the Swedish sawn wood industry. Scand. J. For. Res. 17, 90-96 (2002)

30. Jonsson, R., Egnell, G., Baudin, A.: Swedish Forest Sector Outlook Study. United Nations Economic Commission for Europe. FAO. Geneva Timber For Discuss Pap 58 (2011)

31. EOS: Annual report of the European sawmill industry (2017)

32. FAO: FAOSTAT: Forestry production and trade. Food Agric. Organ. United Nations. https://www.fao.org/faostat/en/\#data/FO (2019). Accessed 17 Sept 2019

33. The sawmill database. The Sawmill Database. https://www. sawmilldatabase.com/ (2019). Accessed 23 Sept 2019

34. Bergquist AK, Andersson LF. Effekter av miljöpolitiska styrmedel i skogsindustrin. In: En Fakta- och Forskningsöversikt R€orande Betydelsen Av Miljöpolitiska Styrmedel För Ökad Hållabarhet Och Konkurrenskraft I Massa-Och Pappersindustrin I Sverige efter 1990, 2013/011. Tillväxtanalys, Östersund, p. 35. 2013.
35. Tillväxtanalys: Den svenska bioekonomins utveckling - Statistik och analys. https://www.tillvaxtanalys.se/publikationer/svar-direk t/svar-direkt/2016-11-02-den-svenska-bioekonomins-utveckling ----statistik-och-analys.html (2019). Accessed 23 Sept 2019

36. Bauer F, Coenen L, Hansen T, McCormick K, Palgan YV. Technological innovation systems for biorefineries: a review of the literature. Biofuels Bioprod. Biorefining; 2017. 11(3): 534-48.

37. Karltorp, K., Sandén, B.A.: Explaining regime destabilisation in the pulp and paper industry. Environ. Innov. Soc. Trans. 2, 66-81 (2012)

38. Pätäri, S., Tuppura, A., Toppinen, A., Korhonen, J.: Global sustainability megaforces in shaping the future of the European pulp and paper industry towards a bioeconomy. For. Policy Econ. 66, 38-46 (2016)

39. Toppinen, A., Pätäri, S., Tuppura, A., Jantunen, A.: The European pulp and paper industry in transition to a bio-economy: a Delphi study. Futures 88, 1-14 (2017)

40. Scordato, L., Klitkou, A., Tartiu, V.E., Coenen, L.: Policy mixes for the sustainability transition of the pulp and paper industry in Sweden. J. Clean Prod. 183, 1216-1227 (2018)

41. Rametsteiner, E., Weiss, G., Ollonqvist, P., Slee, B.: Policy Integration and Coordination: the case of Innovation and the Forest Sector in Europe. COST Action E51 (2010)

42. Hussain J, Bernard J-T. Regional productivity convergence: an analysis of the pulp and paper industries in U.S., Canada, Finland and Sweden. J. For. Econ. 2017;28:49-62.

43. Söderholm, K., Bergquist, A.K., Söderholm, P.: The transition to chlorine free pulp revisited: nordic heterogeneity in environmental regulation and R\&D collaboration. J. Clean Prod. 165, 1328-1339 (2017)

44. Sandberg, M., Venkatesh, G., Granström, K.: Experimental study and analysis of the functional and life-cycle global warming effect of low-dose chemical pre-treatment of effluent from pulp and paper mills. J. Clean Prod. 174, 701-709 (2018)

45. Möllersten, K., Yan, J., Westermark, M.: Potential and cost-effectiveness of $\mathrm{CO} 2$ reductions through energy measures in Swedish pulp and paper mills. Energy. 28, 691-710 (2003)

46. Thollander, P., Ottosson, M.: Energy management practices in Swedish energy-intensive industries. J. Clean Prod. 18, 11251133 (2010)

47. Bergquist, A.K., Söderholm, K.: Sustainable energy transition: the case of the Swedish pulp and paper industry 1973-1990. Energy Effic. 9, 1179-1192 (2016)

48. Ericsson, K., Nilsson, L.J., Nilsson, M.: New energy strategies in the Swedish pulp and paper industry: the role of national and EU climate and energy policies. Energy Policy. 39, 1439-1449 (2011)

49. Korhonen, J., Pätäri, S., Toppinen, A., Tuppura, A.: The role of environmental regulation in the future competitiveness of the pulp and paper industry: the case of the sulfur emissions directive in Northern Europe. J. Clean Prod. 108, 864-872 (2015)

50. IEA. Tracking industrial energy efficiency and $\mathrm{CO}_{2}$ emissions In support of the G8 plan of action. International Energy Agency. Paris. (2007)

51. UNECE: Market Statement 2017 - Sweden. Timber committee market discussion. Warsaw, Poland. https://www.unece.org/filea dmin/DAM/timber/country-info/statements/sweden2017.pdf

52. Gibson, E.: White Arkitekter selected to build timber high-rise in Sweden. https://www.dezeen.com/2016/06/07/kulturhus-iskelleftea-white-arkitekter-cultural-centre-hotel-sweden-woode n-timber-frame/ (2019). Accessed 21 Dec 2019

53. IVA: Klimatpåverkan från byggprocessen - IVA. https://www. iva.se/publicerat/klimatpaverkan-fran-byggprocessen/ (2019). Accessed 23 Sept 2019

54. TMF: Trähusbarometern - TMF. https://www.tmf.se/statistik/stati stiska-publikationer/trahusbarometern/ (2019). Accessed 23 Sept 2019 
55. Statistics Sweden: Agricultural statistics 2017 including food statistics - tables. Official ststistics of Sweden. https://www.scb.se/ publication/35150 (2019). Accessed 22 May 2019

56. Cherubini, F.: The biorefinery concept: using biomass instead of oil for producing energy and chemicals. Energy Convers. Manag. 51, 1412-1421 (2010)

57. de Jong, E., Higson, A., Walsh, P., Wellisch, M.: Biobased chemicals - value added products from biorefineries. IEA BioenergyTask 42 (2011)

58. SEKAB: Biorefinery. https://www.sekab.com/about-us/biorefiner y/ (2019). Accessed 21 Sept 2019

59. RISE: Biorefinery Demo Plant - A boost for your biorefinery development!. https://www.sp.se/en/index/services/biorefiner ydemoplant/Sidor/default.aspx (2019). Accessed 21 Sept 2019

60. Mossberg, J.: Chemical Industry Companies in Sweden - Update Including Data for Competence Analysis. VINNOVA, Stockholm (2016)

61. Bioenergy International: More biorefineries in Sweden will not affect pricing of forest feedstocks I Bioenergy International. https ://bioenergyinternational.com/markets-finance/more-biorefiner ies-in-sweden-will-not-affect-pricing-of-forest-feedstocks (2019). Accessed 16 Sept 2019

62. BIOBUF: Raw material | BioBuF. https://biobuf.se/en/about-biobu f/raw-material/ (2019). Accessed 16 Sept 2019

63. Manolis, E.N., Zagas, T.D., Karetsos, G.K., Poravou, C.A.: Ecological restrictions in forest biomass extraction for a sustainable renewable energy production. Renew. Sustain. Energy Rev. 110, 290-297 (2019)

64. Sveaskog: The climate impact of forest biomass. pp. i:4-5 (2015)

65. Helin T, Sokka L, Soimakallio S, Pingoud K, Pajula T. Approaches for inclusion of forest carbon cycle in life cycle assessment: a review. GCB Bioenergy; 2013. p. 475-86.

66. Miner R, Gaudreault C. A review of biomass carbon accounting methods and implications. National Council for air and stream improvement (NCASI) Tech Bull, North Carolina. 2013;1-52.
67. Zanchi, G., Pena, N., Bird, N.: Is woody bioenergy carbon neutral? A comparative assessment of emissions from consumption of woody bioenergy and fossil fuel. GCB Bioenergy. 4, 761-772 (2012)

68. IPCC: AR5 Climate Change 2013: The Physical Science BasisIPCC https://www.ipcc.ch/report/ar5/wg1/ (2019). Accessed 23 Sept 2019

69. Suttie, E., Hill, C., Sandin, G., Kutnar, A., Ganne-Chédeville, C., Lowres, F., Dias, A.C.: Environmental assessment of bio-based building materials. Chapter 9. In: Jones, D., Brischke, C. (eds.) Performance of bio-based building materials. pp. 547-91. Woodhead publishing, Sawston (2017)

70. Manolis, E.N., Zagas, T.D., Karetsos, G.K., Poravou, S.A.: Spatial limitations in forest biomass harvesting using Geographic Information System and Remote Sensing for an ecological and sustainable bioenergy framework. J. Sustain. For. 37, 712-726 (2018)

71. Folke, C.: Resilience: the emergence of a perspective for socialecological systems analyses. Glob. Environ. Chang. 16, 253-267 (2006)

72. Sandin, G.: Life cycle assessment in the development of forest products. Contributions to improved methods and practices. $\mathrm{PhD}$ thesis, Chalmers University of Technology, Gothenburg, Sweden (2015)

73. Stockholm Resilience Center. Social-ecological systems. https:// www.stockholmresilience.org/ (2007)

Publisher's Note Springer Nature remains neutral with regard to jurisdictional claims in published maps and institutional affiliations. 